\section{PLANT ANATOMY}

\section{Anatomy of the Monocotyledons}

Vol. 3: Commelinales-Zingiberales. By P. B. Tomlinson. Pp. $x x+446$. (Clarendon Press: Oxford; Oxford University Press: London, February 1969.) 105s.

Vol. 4: Juncales. By D. F. Cutler. Pp. ix +357. (Clarendon Press: Oxford; Oxford University Press: London, October 1969.) $100 s$.

THEse two volumos make further substantial progress in the serial publication of the Anatomy of the Monocotyledons. The editor, Dr Metcalf, has now retired from the Royal Botanic Gardens, Kew, but he will continue to edit the series; and both he and the authors of these volumes are to be congratulated on the excellent progress which is being made.

Volume three is in two sections. In the first, Dr Tomlinson deals with the eight families which form Engler's order, the Farinosae, including the Bromeliaceae. The second covers another series of eight families in the order Zingiberales, including the Musaceae. The account of each family begins with several pages of general anatomical description (though, regrettably, a formal description of the family is not given); this is followed by sections, of variable length, on the individual anatomical features. The literature is well covered, and there are many clear diagrams and drawings. The text is chiefly designed for reference, but it is well written and set out, so that it is comparatively easy to gain an impression of the anatomical features of a family. There are some special scctions, such as that on the ecological anatomy of the Bromeliaceae, which are brilliantly done. There are short appendices on the distribution of diagnostic features in the families, which will be of use in identification, and there is also an interesting short discussion on stomatal ontogeny. Some taxonomic problems, in both orders, are discussed in the light of the new anatomical evidence available, and the weight of this evidence is assessed. The amount of original work presented is large, and the volume represents a major contribution to our knowledge of tropical monocotyledons.

Volume four differs in several ways from volume three. Dr Cutler deals with only a single order, tho Juncales, with six families, in a book which is three-quarters the longth of volume three; and the treatment, which is of a high standard in both text and illustrations, is accordingly much more detailed. In particular, 215 pages are devoted to the Restionaceae, a family of the southern hemisphere. This account consists of a general introduction (but again, there is no formal description), followed by an artificial key to the twenty-four genera. The anatorny of each genus is then doscribed, the genera being arranged alphabetically. Some of the descriptions are very detailed; thus 50 pages are devoted to the genus Restio, of which eighty-four species have been examined anatomically by the author. This very thorough treatment is not only important for identification and morphological study; it has considerable potential value as a means of elucidat. ing the taxonomy of the group in relation to its geographical distribution. While this aspect of the matter is not omitted in the author's account, it is not, in my view, given sufficient prominence, nor are the threads drawn together as neatly as they might bo. Thus, three somewhat inconsistent statements are made (p. viii, p. 116 and p. 296) about the South African and Australian species of Restio and whether they should continue to be regarded as being within the compass of a single genus. This is a question of great phytogoographical interest. It is unlikely that anybody knows more about it than Cutler; and it is a pity that he has not been able to devote a few pages to a critical discussion and a decision.

Both volumes are well printed and indexed and are reasonably priced.

\section{GREENFINGERS IN AMERICA}

\section{A Short History of Botany in the United States}

Edited by Joseph Ewan. Pp. ix +174 . (Hafner: New York and London, 1969.) $\$ 7.50$.

Host countries to international botanical congresses in recent years have provided participants with a brief guide to their country's contribution to the development of botanical science. The proceedings of the eleventh International Botanical Congress, which was held in Seattle in August 1968, are reported in this volume. It outlines the growth of knowledge of the floral richness of the United States, and the important role of American botanists in the advance of botanical research. The type of presentation, a volume of essays by experts in their respective fields, is not ideal, but the method was obviously dictated by the short space of time available for the volume's production. Professor Joseph Ewan, one of the leading historians of biological science in the United States, has contributed two essays and edited the other contributions. His essay, "Early History", opens the door to the fascinating story of the gradual discovery of the natural wealth of America. Many of the carly naturalists came from Great Britain and later in the early nineteenth century a number of British plantsmen conserved and enhaneed the floral wealth of the USA. This contribution was in no way one-sided, for many of tho garden plants and trees loved today in Great Britain came from America in the seventeenth and eightcenth centuries. Britain's countryside and the gardens of many famous country houses were also greatly enhanced at that period by the extensive planting of American trees.

The other essays deal largely with post-World War II advances. The individual treatment of these subjects is unavoidably uneven, but they present a useful record. The essays could not be more concise. The editor has wisely ornitted references to the published work of the various botanists mentioned. This detail can, however, be obtained from consulting the items given in the list of "Recommended Reading". The "Calendar of Evonts", a chronological list of important American events, discoveries and publications of botanically" significant works, is a unique feature which with the "Index of Persons" giving birth and death dates must have been a labour of love on the part of the editor. I have noted one error in the "Calendar"-Schweintz, L. D. de Snyopsis fungorum Carolinae ... is listed as being published in 1818 whereas it should have appeared under the date $\mathbf{1 8 2 2}$.

This book will prove a valuable, no to date, quick reference to the development of botanical seience in general and the achievements of American botanists in particular. The editor and the publishers are to be congratulated on producing an attractive publication which should be in every botanical library. Phyllis I. Edwards

\section{AUSTRALIAN GEOLOGY}

\section{Stratigraphy and Palaeontology}

Essays in Honour of Dorothy Hill. Edited by K. S. W. Campbell. Pp. xxiii + 390. (Australian National University Press: Canberra, October 1969.) \$A17.50.

THIs volume consists of twenty papers of varying length distributed into four groups: interpretative palaeontology, biostratigraphy and biogeography; descriptivo palaeontology and palaeoecology; geomorphology; and sedimentation.

In the first group, Bulrnan demonstrates that prothecal folds originated more than once among graptolites and that Dicellograptus is probably polyphyletic. Wells indicates that details of the actual growth of dissepiments have not been dircetly observed in recent corals, but the growth patterns support the idea that it is centripetal. 